\title{
The Effect of the Aminic Substituent on the Thermal Decomposition of Cyclic Dithiocarbamates
}

\author{
Éder T.G. Cavalheiro ${ }^{\mathrm{a}}{ }^{*}$, Massao Ionashiro ${ }^{\mathrm{b}}$, Glimaldo Marino ${ }^{\mathrm{c}}$, \\ Susete T. Breviglieri ${ }^{\mathrm{c}}$, and Gilberto O. Chierice ${ }^{\mathrm{c}}$ \\ a Depto. Química, UFSCar, São Carlos, São Paulo, CP 676, \\ 13565-905 São Carlos - SP,Brazil; cavalheiro@dq.ufscar.br; \\ ${ }^{\mathrm{b}}$ Instituto de Química, UNESP, Araraquara, São Paulo, CP 355, \\ 14800-900 Araraquara - SP, Brazil \\ cInst. de Química de S. Carlos, USP, São Carlos, São Paulo, CP 780, \\ 13560-970 São Carlos - SP, Brazil
}

Received: September 29, 1998

\begin{abstract}
Estudos termogravimétricos e calorimétricos diferenciais para ditiocarbamatos de $\mathrm{NH}_{4}{ }^{+}, \mathrm{Na}^{+}$,

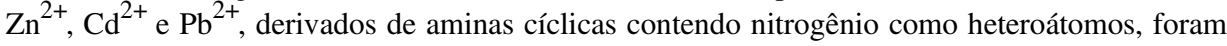
realizados em atmosferas de ar e nitrogênio, para avaliar a influência da tensão angular dos anéis na decomposição térmica destes compostos, em relação à formação de tiocianatos metálicos como via de decomposição. Os intemediários formados foram caracterizados por difração de raios-X, tendo

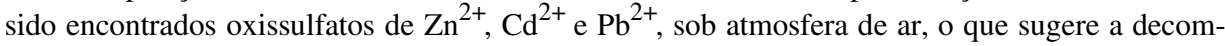
posição térmica nestas condições como via sintética para estes compostos. Os produtos de decomposição final obtidos foram sulfetos metálicos sob nitrogênio e óxidos dos metais de transição e sulfato de sódio sob ar. Entalpias de fusão são também descritas, com base nos resultados de DSC.

Thermogravimetric and Differential Scanning Calorimetric investigation of the thermal behaviour of $\mathrm{NH}_{4}^{+}, \mathrm{Na}^{+}, \mathrm{Zn}^{2+}, \mathrm{Cd}^{2+} \mathrm{e} \mathrm{Pb}^{2+}$ dithiocarbamates obtained from cyclic amines, is described under nitrogen and air atmospheres in order to investigate the effect of a cyclic ring on the mechanism of decomposition. Intermediates were identified by X-ray Diffraction analysis. $\mathrm{Zn}^{2+}, \mathrm{Cd}^{2+} \mathrm{e} \mathrm{Pb}^{2+}$ oxysulphates were detected under air atmosphere suggesting the thermal decomposition under these conditions as an alternating synthetic route to prepare those compounds. The final decomposition products were the metallic sulphides under $\mathrm{N}_{2}$ atmosphere while transition metal oxides and sodium sulphate were obtained under air. Melting enthalpies are also reported from DSC data.
\end{abstract}

Keywords: dithiocarbamates, thermogravimetry, differential scanning calorimetry, decomposition mechanism

\section{Introduction}

Dithiocarbamates (DTC), are products of a reaction of a primary or secondary amines with carbon disulphide, and has been described in several applications such as medicine, industry, agriculture and chemistry, that are commented in several reviews ${ }^{1-9}$.

In those reviews is possible to note that the knowledge of DTC thermal behaviour and information about their stability and decomposition residues, are important data and can show synthetic routes for unusual compounds.

In three reviews about the thermal behaviour of DTC compounds $^{1,2,4}$, most of references are related with the aliphatic derivatives in which a decomposition mechanism involving metallic thiocyanate as the main intermediate. However, few studies has been presented in relation to the cyclic DTC, such as pyrrolidinedithiocarbamate (Pyr) and 
piperidinedithiocarbamate (Pip), in which the formation of the thiocyanate must be related with cleavage of $\mathrm{C}-\mathrm{N}$ bond in the ring.

Pyr complexes are widely used in solvent extraction and other analytical procedures, because of their resistance to acidic media ${ }^{10}$. In applications such as in atomic absorption spectrophotometry, the thermal decomposition data can help in understanding more about atomization mechanisms of those complexes ${ }^{11}$.

The Pip complexes of $\mathrm{Zn}$ and $\mathrm{Cd}$ are largely applied as curing agents in rubber processing ${ }^{12}$ and in photographic films ${ }^{13,14}$ were the thermal behaviour is an important feature.

Recently Fernandez-Alba et al. ${ }^{15}$, reported studies on thermal decomposition of $\mathrm{NH}_{4} \mathrm{Pyr}$ and other DTC, with agricultural applications. Vibrational Spectroscopy was used to propose an structure to the complexes.

Diaz et al. ${ }^{16}$ studied decomposition fragments in mass spectroscopy for $\mathrm{Bi}, \mathrm{Cd}, \mathrm{Co}, \mathrm{Cr}, \mathrm{Cu}, \mathrm{Fe}, \mathrm{Ni}, \mathrm{Pb}, \mathrm{Sb}, \mathrm{Zn}$ and ammonium in Pyr compounds.

Gomicek et al. ${ }^{17}$, presented X-ray diffraction studies for the characterisation of decomposition products of several Pyr complexes with divalent cations. The decomposition products were obtained at 80, 150, 250, 300, 400 and $600{ }^{\circ} \mathrm{C}$, under oxygen and argon atmospheres. The compounds were obtained in an oven without use of the TG to follow up the thermal decomposition pathways.

The same authors ${ }^{18}$, investigated the thermal behaviour of $\mathrm{Cd}, \mathrm{Co}, \mathrm{Cu}, \mathrm{Fe}, \mathrm{Ni}, \mathrm{Pb}$ and $\mathrm{V}$ - Pyr complexes in graphite tubes for atomic absorption.

Sceney et al. ${ }^{19}$, studied the thermal decomposition of seven copper(II) dithiocarbamates by thermogravimetry, under air and nitrogen atmospheres. Complete TG and DTA studies are reported to copper(II)-diethyldithiocarbamate complex under air, vacuum and nitrogen.

It is also important to note that few DSC results, about thermal DTC behaviour has been previously reported. The most thermal differential data are from DTA results.

In the present work the thermal behaviour of ammonium, sodium, zinc, cadmium and lead complexes with Pyr and Pip under nitrogen and air atmospheres was investigated with the purpose of evaluating the influence of the different angular tension of the 5 and 6 members aminic rings on the decomposition and identify the intermediates formed.

\section{Experimental}

Syntesis of the ligands and complexes

Ammonium and sodium salts of the ligands, were prepared by direct reaction between the piperidine or pyrrolidine and carbon disulphide in basic media and recrystallised from acetone $\left(\mathrm{NH}_{4} \mathrm{Pip}\right)$ or ethanol-water 1:1 (v/v) (NaPip,
$\mathrm{NaPyr}$ and $\mathrm{NH}_{4} \mathrm{Pyr}$ ) and then dried in a vacuum oven at $50{ }^{\circ} \mathrm{C}$, for $8 \mathrm{~h}$.

The metallic complexes were obtained by direct reaction of the DTC sodium salt and a soluble salt of the desired cation. The resulting precipitates were filtered, washed with acetone and dried as above.

\section{Equipment}

Characterazation of the compounds was performed using Vibrational Spectroscopy ( $\mathrm{KBr}$ pellets) in a Nicolet 5SXC spectrophotometer; NMR- ${ }^{1} \mathrm{H}$ in a Brücker AC-200 spectrometer and Flame Atomic Absorption Spectroscopy in an Intralab AA12/1475 (Gemini) spectrophotometer and Elemental Analysis using a Fisons EA 1108 CNHS-O instrument.

TG curves were recorded in a DuPont 9900 thermoanalyser coupled with a TGA 951 Thermogravimetric Module under a gas flow of $200 \mathrm{~mL} \mathrm{~min}^{-1}\left(\mathrm{~N}_{2}\right.$ or air), in a platinum crucible, at $10^{\circ} \mathrm{C} \mathrm{min}{ }^{-1}$ heating rate and using samples of about $7 \mathrm{mg}$ of each compound at atmospheric pressure. For the ammonium salts (Pyr and Pip), the TG experiments were carried out only in nitrogen. The DSC curves were recorded in a DuPont 9900 thermoanalyser coupled with a DSC 910 Calorimetric Module under a gas flow of $200 \mathrm{~mL}$ $\min ^{-1}\left(\mathrm{~N}_{2}\right.$ or air), in aluminium hermetic pans, at $10^{\circ} \mathrm{C} \mathrm{min}{ }^{-1}$ heating rate and using samples of about $5 \mathrm{mg}$ of each compound at atmospheric pressure.

$\mathrm{X}$-ray diffraction patterns of intermediates and final products, were obtained in an HZ-Karl Zeiss or a D5.000 Siemens diffractometers. The melting points were also determined in a dry furnace Electrothermal digital melting point apparatus.

Fusion enthalpies were determined by DSC after calibration of the equipment with indium metal. The area of the melting peak for this metal was stored in the system and compared with the area of sample melting peaks in a standard procedure. Temperatures are also measured in relation to the In fusion, calibration.

\section{Results and Discussion}

The structural formula of the ligands are:

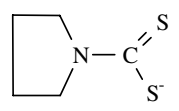

Pyr

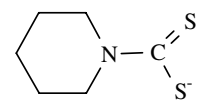

Pip
The proposition of the earlier works for thiocyanate ${ }^{1}$ as the decomposition intermediate implies that the decomposition of the DTC complexes occurs with rupture of C-N-C bonds. For a divalent cation-Pyr complex we can propose:

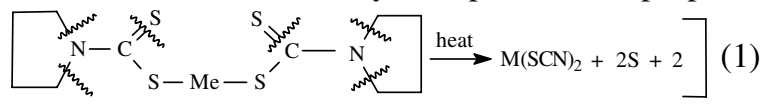

The differences in the angular tension between the 5 and 6 membered rings of pyrrolidine and piperidine respec- 

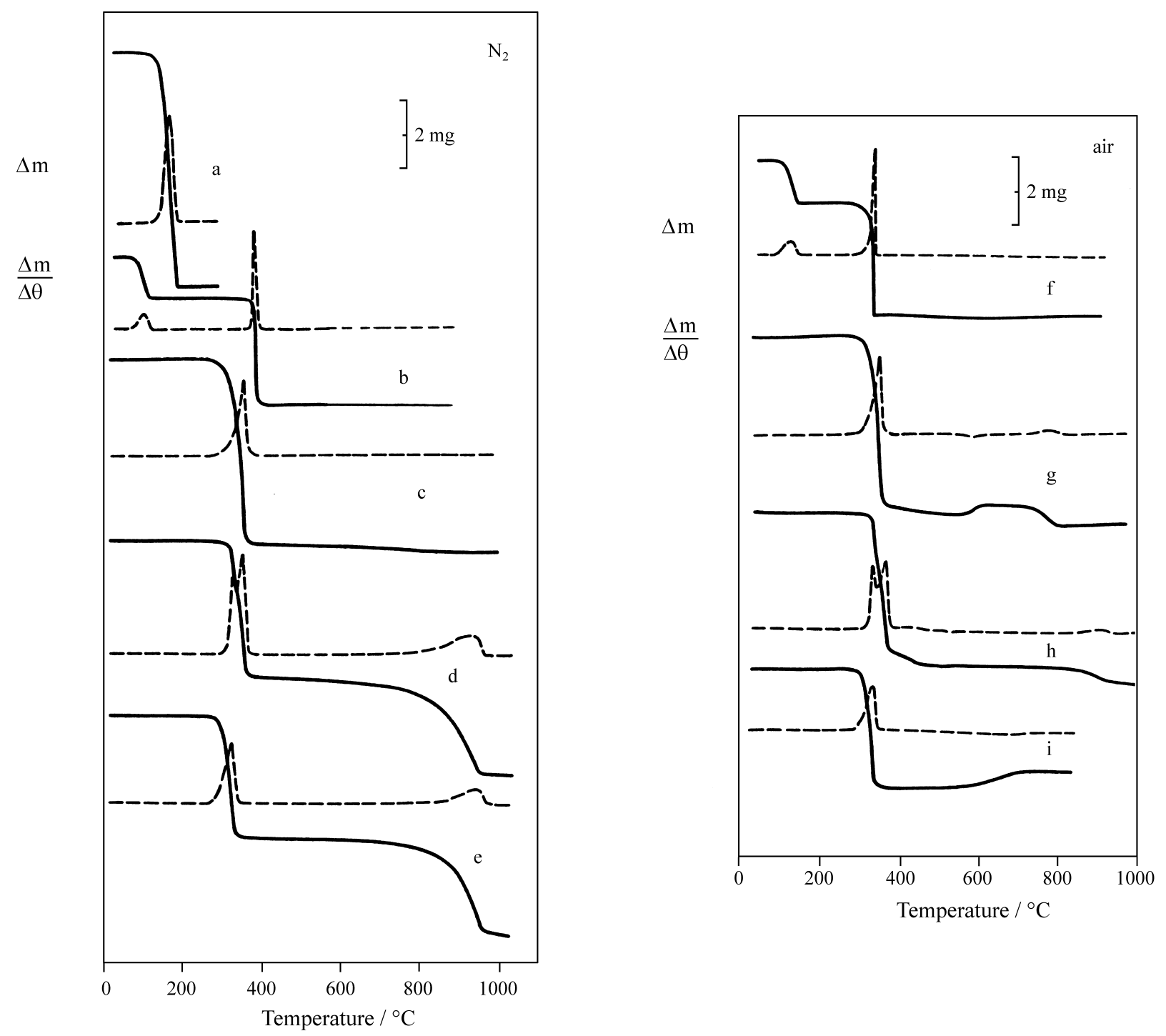

Figure 1. TG (solid line) and DTG (dashed line) curves for the Pyrrolidinedithiocarbamates under $\mathrm{N}_{2}$ atmosphere: a) $\mathrm{NH}_{4}^{+}$; b) $\mathrm{Na}^{+}$; c) $\mathrm{Zn}^{2+}$; d) $\mathrm{Cd}^{2+}$; e) $\mathrm{Pb}^{2+}$; and under air: f) $\mathrm{Na}^{+} ;$g) $\mathrm{Zn}^{2+}$; h) $\mathrm{Cd}^{2+}$ and i) $\mathrm{Pb}^{2+}$.

tively suggests that Pyr derivatives, a more tense 5 member ring, are supposed to decompose preferentially by the thiocyanate.

However the results obtained here suggest the decomposition in a direct way (except to $\mathrm{CdPyr}_{2}$ ), without the thiocyanates as the main decomposition pathway, in agreement with some observations of Fernandez-Alba et al. ${ }^{15}$

The spectrometric characterisation results are shown in Table 1 and the elemental analysis data for all the compounds are shown is in Table 2. The TG-DTG curves for Pyrrolidinedithicarbamates are shown in Fig. 1 under nitrogen and air atmospheres. The DSC curves under both atmospheres are in Fig. 2.

Mass losses, temperature ranges and residues for the decomposition of all Pyr compounds are described in Ta- ble 3 . The melting points and enthalpies are shown in Table 4.

$\mathrm{NH}_{4} \mathrm{Pyr}$

The TG/DTG curves of ammonium salt showed a single decomposition step between 70 and $175^{\circ} \mathrm{C}$ (Fig 1.a) without residues on the crucible. The DSC curves of ammonium salt showed endothermic peaks at $139,164,191$ and $199^{\circ} \mathrm{C}$ under nitrogen atmosphere (Fig. 2.a). Under air (Fig. 2.f) the peaks are at $141,163,186$ and $195^{\circ} \mathrm{C}$.

In order to attribute the peaks a sample was heated in a glass tube $(20 \times 2 \mathrm{~cm})$ immerse in a glycerine bath. Around $140{ }^{\circ} \mathrm{C}$ the gas produced by heating the sample was bubbled into a phenolphtalein solution turning it to red and showed a characteristic smell of ammonia ${ }^{26}$. Near $150{ }^{\circ} \mathrm{C}$ melting 
of sample was observed producing a brown viscous liquid, which IR spectra suggests that it is the HPyr (Table 1). The gas at $165^{\circ} \mathrm{C}$ when bubbled in a $\mathrm{Sb}^{3+}$ solution produced an orange solid and showed a characteristic smell of $\mathrm{H}_{2} \mathrm{~S}$. The colour is characteristic for $\mathrm{Sb}_{2} \mathrm{~S}_{3}{ }^{26}$.
According to these observations it was shown that the $\mathrm{NH}_{4} \mathrm{Pyr}$ decomposes by the following steps:

$$
\begin{aligned}
& \mathrm{NH}_{4} \mathrm{Pyr} \rightarrow \mathrm{NH}_{3}+\mathrm{Hpyr} \\
& \operatorname{HPyr}_{(\mathrm{s})} \rightarrow \operatorname{HPyr}_{(1)}
\end{aligned}
$$

\begin{tabular}{|c|c|c|c|c|c|}
\hline \multirow[t]{2}{*}{ Compound } & \multirow{2}{*}{$\begin{array}{c}\mathrm{UV} \\
\lambda_{\mathrm{MAX}} / \mathrm{nm}(\log ) \\
\end{array}$} & \multicolumn{3}{|c|}{ IR bands $/ \mathrm{cm}^{-1}$} & \multirow{2}{*}{$\begin{array}{c}\text { NMR } \\
v / \mathrm{ppm}\end{array}$} \\
\hline & & $v(\mathrm{C}=\mathrm{S})$ & $v\left(\mathrm{~N}-\mathrm{CS}_{2}\right)$ & $v(\mathrm{C}-\mathrm{N})$ & \\
\hline HPyr & & 996 & 1160 & 1455 & \\
\hline $\mathrm{NH}_{4} \mathrm{Pyr}$ & $264(4.0)-280(4.0)^{\mathrm{a}}$ & 996 & 1159 & 1392 & $1.9 ; 3.4 ; 3.8$ \\
\hline $\mathrm{NaPyr}$ & $264(4.0)-280(4.0)^{\mathrm{a}}$ & $998^{(1005 c)}$ & $1160^{(1129 c)}$ & $1421^{(1420 c)}$ & $1.8 ; 3.5$ \\
\hline $\mathrm{ZnPyr}_{2}$ & & 1003 & 1161 & $1482^{(1485 d)}$ & $2.0 ; 3.7$ \\
\hline Cd Pyr2 & & 994 & 1160 & $1471^{(1475 e)}$ & $\mathrm{f}$ \\
\hline $\mathrm{Pb} \mathrm{Pyr}_{2}$ & & 1000 & 1162 & $1509^{(1460 \mathrm{e})}$ & $2.0 ; 3.8$ \\
\hline $\mathrm{NH}_{4} \mathrm{Pip}$ & $256(4.1)-278(4.0)^{\mathrm{a}}$ & 993 & 1117 & 1400 & $1.6 ; 1.8 ; 3.2 ; 3.6$ \\
\hline NaPip & $256(4.1)-278(4.0)^{\mathrm{a}}$ & $1005^{(1003 c)}$ & $1110^{(1110 c)}$ & $1470^{(1465 b)}$ & $1.4 ; 2.0 ; 4.0$ \\
\hline $\mathrm{ZnPip}_{2}$ & & 979 & 1113 & 1484 & $1.5 ; 1.7 ; 4.0$ \\
\hline Cd Pip2 & & 975 & 1112 & 1482 & $1.5 ; 1.7 ; 4.1$ \\
\hline $\mathrm{Pb} \mathrm{Pip}_{2}$ & & 973 & 1002 & 1464 & $1.5 ; 1.7 ; 3.9$ \\
\hline
\end{tabular}

Table 1. Molecular absorption spectrometry (UV), infrared spectrometry (IR) and nuclear magnetic resonance ${ }^{1} \mathrm{H}$ (NMR) data obtained for the compounds.

a. in agreement with Ref. 20, 21; b. Ref. 22; c. Ref. 23; d. Ref. 24; e. Ref. 25; f. insoluble in deutered water.

\begin{tabular}{|c|c|c|c|c|c|}
\hline Compound & & Metal & $\mathrm{C}$ & $\mathrm{H}$ & $\mathrm{N}$ \\
\hline \multirow[t]{2}{*}{$\mathrm{NH}_{4} \mathrm{Pyr}$} & calc. & - & 36.55 & 7.38 & 17.05 \\
\hline & found & - & 36.59 & 7.61 & 17.11 \\
\hline \multirow[t]{2}{*}{$\mathrm{NaPyr} .2 \mathrm{H}_{2} \mathrm{O}$} & calc. & 11.20 & 29.25 & 5.90 & 6.82 \\
\hline & found & 10.90 & 29.31 & 5.83 & 6.87 \\
\hline \multirow[t]{2}{*}{$\mathrm{ZnPyr}_{2}$} & calc. & 18.26 & 33.55 & 4.51 & 7.89 \\
\hline & found & 18.79 & 33.57 & 4.62 & 7.81 \\
\hline \multirow[t]{2}{*}{$\mathrm{Cd} \mathrm{Pyr}_{2}$} & calc. & 27.76 & 29.66 & 3.99 & 6.92 \\
\hline & found & 27.20 & 29.69 & 3.90 & 6.88 \\
\hline \multirow[t]{2}{*}{$\mathrm{Pb} \mathrm{Pyr}_{2}$} & calc. & 41.46 & 24.03 & 3.23 & 5.61 \\
\hline & found & 40.50 & 24.15 & 3.30 & 5.66 \\
\hline \multirow[t]{2}{*}{$\mathrm{NH}_{4} \mathrm{Pip}$} & calc. & - & 40.41 & 7.93 & 15.71 \\
\hline & found & - & 39.98 & 7.84 & 15.79 \\
\hline \multirow[t]{2}{*}{$\mathrm{NaPip} .2 \mathrm{H}_{2} \mathrm{O}$} & calc. & 10.48 & 32.85 & 6.45 & 6.39 \\
\hline & found & 10.79 & 32.92 & 6.51 & 6.25 \\
\hline \multirow[t]{2}{*}{$\mathrm{ZnPip}_{2}$} & calc. & 16.94 & 37.34 & 5.23 & 7.26 \\
\hline & found & 17.46 & 37.41 & 5.19 & 7.21 \\
\hline \multirow[t]{2}{*}{$\mathrm{Cd} \mathrm{Pip}_{2}$} & calc. & 25.96 & 33.29 & 4.66 & 6.47 \\
\hline & found & 25.80 & 33.21 & 4.60 & 6.52 \\
\hline \multirow[t]{2}{*}{$\mathrm{Pb} \mathrm{Pip}_{2}$} & calc. & 39.26 & 27.31 & 3.83 & 5.31 \\
\hline & found & 40.69 & 27.40 & 3.74 & 5.28 \\
\hline
\end{tabular}

Table 2. Analytical data of the compounds (\%). 
Table 3. Mass loses and temperature range corresponding to the decomposition of the pyr compounds.

\begin{tabular}{|c|c|c|c|}
\hline \multirow[t]{2}{*}{ Thermal Process } & \multirow[t]{2}{*}{ Temp. Interval $/{ }^{\circ} \mathrm{C}$} & \multicolumn{2}{|c|}{ Mass Loss or residue/ \% } \\
\hline & & TG & Calc. \\
\hline \multicolumn{4}{|l|}{$\mathrm{N}_{2}$ Atmosphere } \\
\hline $\mathrm{NaPyr} .2 \mathrm{H}_{2} \mathrm{O} \rightarrow \mathrm{NaPyr}+2 \mathrm{H}_{2} \mathrm{O}$ & $61-131$ & $17.6^{\mathrm{a}}$ & 17.5 \\
\hline $\mathrm{NaPyr} \rightarrow \mathrm{Na}_{2} \mathrm{~S}_{3.3}$ & $340-394$ & $36.5^{\mathrm{b}}$ & 37.0 \\
\hline $\mathrm{ZnPyr}_{2} \rightarrow \mathrm{ZnS}(+\mathrm{Zn})$ & $243-389$ & $22.0^{\mathrm{b}}$ & 25.9 \\
\hline $\mathrm{ZnS} \rightarrow \mathrm{Zn}$ & $389-811$ & $18.5^{\mathrm{b}}$ & 18.3 \\
\hline $\mathrm{CdPyr}_{2} \rightarrow \mathrm{CdS}(+\mathrm{C})$ & $280-421$ & $42.5^{\mathrm{b}}$ & 35.7 \\
\hline $\mathrm{CdS}_{(\mathrm{S})} \rightarrow \mathrm{CdS}_{(\mathrm{g})}$ & $566-961$ & $0^{\mathrm{b}}$ & 3.52 \\
\hline $\mathrm{PbPyr}_{2} \rightarrow \mathrm{PbS}$ & $272-390$ & $49.5^{\mathrm{b}}$ & 48.0 \\
\hline $\mathrm{PbS}_{(\mathrm{s})} \rightarrow \mathrm{PbS}_{(\mathrm{g})}$ & $673-1030$ & $0^{\mathrm{b}}$ & 9.02 \\
\hline \multicolumn{4}{|l|}{ Air Atmosphere } \\
\hline $\mathrm{NaPyr} .2 \mathrm{H}_{2} \mathrm{O} \rightarrow \mathrm{NaPyr}+2 \mathrm{H}_{2} \mathrm{O}$ & $71.7-130$ & $17.5^{\mathrm{a}}$ & 17.5 \\
\hline $\mathrm{NaPyr} \rightarrow \mathrm{Na}_{2} \mathrm{SO}_{4}$ & $217-324$ & $35.2^{\mathrm{b}}$ & 34.6 \\
\hline $\mathrm{ZnPyr}_{2} \rightarrow \mathrm{ZnS}$ & $250-479$ & $26.7^{\mathrm{b}}$ & 27.2 \\
\hline $\mathrm{ZnS} \rightarrow \mathrm{ZnSO}_{3}+\mathrm{ZnS}$ & $540-594$ & $30.4^{b}$ & - \\
\hline $\mathrm{ZnSO}_{3}+\mathrm{ZnS} \rightarrow \mathrm{ZnO}$ & $711-788$ & $21.7^{\mathrm{b}}$ & 22.7 \\
\hline $\mathrm{CdPyr}_{2} \rightarrow \mathrm{CdS}$ & $277-470$ & $33.9^{\mathrm{b}}$ & 35.7 \\
\hline $\mathrm{CdS} \rightarrow \mathrm{Cd}_{3} \mathrm{OSO}_{4}$ & $564-670$ & $37.5^{b}$ & 37.0 \\
\hline $\mathrm{Cd}_{3} \mathrm{OSO}_{4} \rightarrow \mathrm{CdO}$ & $779-942$ & $31.4^{b}$ & 31.7 \\
\hline $\mathrm{PbPyr}_{2} \rightarrow \mathrm{PbS}+\mathrm{PbSO}_{4}$ & $272-367$ & $51.2^{b}$ & - \\
\hline $\mathrm{PbS} \rightarrow \mathrm{PbSO}_{4}$ & $367-711$ & $59.0^{\mathrm{b}}$ & 60.7 \\
\hline
\end{tabular}

- not calculated, mixture; a: relative to a mass loss; b: relative to the residue.

Table 4. Melting points and energies, determined by dsc and capillary tubes.

\begin{tabular}{|c|c|c|c|c|}
\hline \multirow[t]{2}{*}{ Compound } & \multirow[t]{2}{*}{ Atmosphere } & \multicolumn{2}{|c|}{ DSC } & \multirow[t]{2}{*}{ Capillary $/{ }^{\circ} \mathrm{C}$} \\
\hline & & Temperature $/{ }^{\circ} \mathrm{C}$ & $\Delta_{\text {fus }} \mathrm{H}_{\mathrm{m}} / \mathrm{J} \mathrm{mol}^{-1}$ & \\
\hline $\mathrm{NH}_{4} \mathrm{Pyr}$ & $\mathrm{N}_{2} /$ air & 163.8 & $*$ & 150 \\
\hline \multirow[t]{2}{*}{$\mathrm{ZnPyr}_{2}$} & $\mathrm{~N}_{2}$ & 293.8 & 25.3 & 294 \\
\hline & air & 293.6 & 25.3 & \\
\hline \multirow[t]{2}{*}{$\mathrm{PbPyr}_{2}$} & $\mathrm{~N}_{2}$ & 286.0 & 37.5 & 286 \\
\hline & air & 285.1 & 34.2 & \\
\hline \multirow[t]{2}{*}{ NaPip } & $\mathrm{N}_{2}$ & 301.7 & 19.7 & 296 \\
\hline & air & $* *$ & $* *$ & \\
\hline \multirow[t]{2}{*}{$\mathrm{ZnPip}_{2}$} & $\mathrm{~N}_{2}$ & 228.4 & 36.9 & 228 \\
\hline & air & 228.2 & 35.4 & \\
\hline \multirow[t]{2}{*}{$\mathrm{CdPip}_{2}$} & $\mathrm{~N}_{2}$ & 258.2 & 30.3 & 259 \\
\hline & air & 258.3 & 30.1 & \\
\hline \multirow[t]{2}{*}{$\mathrm{PbPip}_{2}$} & $\mathrm{~N}_{2}$ & 244.6 & 37.5 & 244 \\
\hline & air & 258.1 & 35.9 & \\
\hline
\end{tabular}

* base line not clear for integration procedure; ** masked by the decomposition process. 

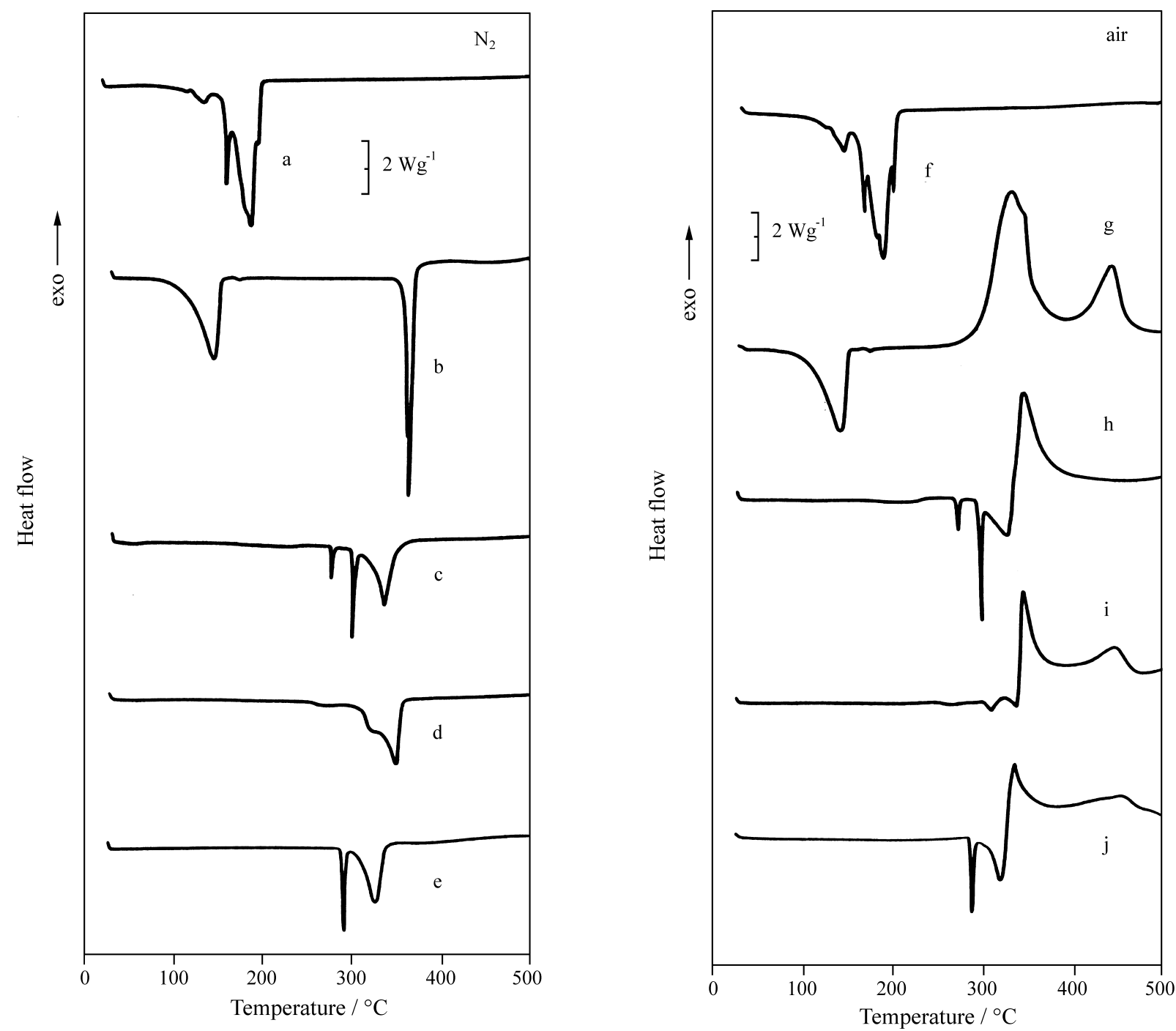

Figure 2. DSC curves for the Pyrrolidinedithiocarbamates under $\mathrm{N}_{2}$ atmosphere: a) $\mathrm{NH}_{4}^{+}$; b) $\mathrm{Na}^{+}$; c) $\mathrm{Zn}^{2+}$; d) $\mathrm{Cd}^{2+}$; e) $\mathrm{Pb}^{2+}$; and under air: f) $\mathrm{NH}_{4}^{+}$g) $\mathrm{Na}^{+}$; h) $\mathrm{Zn}^{2+}$; i) $\mathrm{Cd}^{2+}$ and j) $\mathrm{Pb}^{2+}$.

$$
\operatorname{HPyr}_{(1)} \rightarrow \mathrm{H}_{2} \mathrm{~S}+\text { other volatiles }
$$

As the DSC experiments were carried out in an hermetic crucible the temperatures are higher than the observed in the open tube. These observations are not described in the earlier reports. When the DSC experiment is carried out in an open crucible, a single peak at $155^{\circ} \mathrm{C}$ is observed, under both atmospheres. In the TG experiments these features are not observed probably because the crucible is open.

NaPyr

Sodium salt showed the decomposition in two steps, relative to the loss of $2 \mathrm{H}_{2} \mathrm{O}$, with sodium polissulphide and a carbonaceous residue under nitrogen atmosphere (340$394{ }^{\circ} \mathrm{C}$ ) according to Figure 1.b and sodium sulphate air (Fig. 1.f), and it was the most stable compound in the series here studied. The presence of the polisuphide is in agree- ment with the observed in earlier works ${ }^{27,28}$, and were characterised by X-ray diffraction.

The DSC curves for sodium salt evidenced peaks attributed to a loss of water and decomposition under $\mathrm{N}_{2}$ (Fig. 2.b). The experiment carried out in air (Fig. 2.g) showed the loss of water followed by exothermic processes of decomposition and oxidation to $\mathrm{Na}_{2} \mathrm{SO}_{4}$, respectively.

\section{$\mathrm{ZnPyr}_{2}$}

TG/DTG curves of zinc compound showed decomposition in a single step resulting mainly in $\mathrm{ZnS}$ and a small amount of $\mathrm{Zn}{ }^{\circ}$ in the residue under nitrogen (Fig. 1.c). This mixture is slowly reduced up to $811{ }^{\circ} \mathrm{C}$ producing $\mathrm{Zn}^{\circ}$. Under air (Fig. 1.g) three steps were observed. The first was the decomposition and formation of $\mathrm{ZnS}$, followed by 
production of $\mathrm{ZnSO}_{3}$ and $\mathrm{ZnS}$ and pure $\mathrm{ZnO}$. All these data were confirmed by X-ray diffraction data.

The DSC curves under $\mathrm{N}_{2}$ atmosphere (Fig. 2.c), showed a endothermic peak at $269^{\circ} \mathrm{C}\left(\Delta \mathrm{H}=8.32 \mathrm{~kJ} \mathrm{~mol}^{-1}\right)$, attributed to a crystalline phase change followed by a melting process, coincident with the observation in a capillary tube. The endothermic peak at $331^{\circ} \mathrm{C}$, was attributed to decomposition of the compound. Under air atmosphere (Fig. 2.h) endothermic peaks at $268{ }^{\circ} \mathrm{C}(\Delta \mathrm{H}=8.40 \mathrm{~kJ}$ $\mathrm{mol}^{-1}$ ), and at $294{ }^{\circ} \mathrm{C}$, were attributed to crystalline phase change and melting respectively, in agreement with the data under nitrogen atmosphere. The decomposition of the complex is represented by endothermic peaks at 325 and exothermic at $346{ }^{\circ} \mathrm{C}$. $\mathrm{ZnPyr}_{2}$, is the unique compound that showed crystalline phase transition in the present series.

\section{CdPyr 2}

The TG curves in $\mathrm{N}_{2}$ atmosphere (Fig. 1.d) showed the decomposition with generation of $\mathrm{CdS}$ and a amorphous material according the X-ray diffraction data. The black amorphous material was insoluble in $\mathrm{HCl}$ and was suspect to carbonaceous residue.

The DTG curve suggests that the first step is split in two consecutive reactions. This could be related with the formation of thiocyanide considering that the $\mathrm{Cd}^{2+}$ is soft acid with affinity to soft base represented by that anion, according to Pearson's concept ${ }^{29}$ and the weakening of the C-N ring bonds by angular tension. Above $566{ }^{\circ} \mathrm{C}$ volatilisation of the $\mathrm{CdS}$ is observed, represented by a yellow substance impregnating the exhausting furnace tube, with black residue of $3.6 \%$ at the crucible, probably carbon.

Under air atmosphere (Fig. 1.h) the residues showed the presence of $\mathrm{CdS}$ at $400{ }^{\circ} \mathrm{C}$ and pure $\mathrm{Cd}_{3} \mathrm{OSO}_{4}$ at $700{ }^{\circ} \mathrm{C}$. The final residue is $\mathrm{CdO}$. All these results were confirmed by $\mathrm{X}$-ray diffraction data.

The DSC curves do not evidenced the occurrence of melting in agreement with capillary tube observation. Under $\mathrm{N}_{2}$ atmosphere (Fig. 2.d), is possible to note the decomposition, related with the endothermic peaks at 320 and $345^{\circ} \mathrm{C}$. Under air atmosphere (Fig. 2.i) decomposition is represented by the peaks at $309,336{ }^{\circ} \mathrm{C}$ and $346{ }^{\circ} \mathrm{C}$ in agreement with TG data. The exothermic processes at $446{ }^{\circ} \mathrm{C}$, was attributed to carbon burning.

\section{$\mathrm{PbPyr}_{2}$}

Under nitrogen atmosphere (Fig. 1.e) the $\mathrm{PbPyr}_{2} \mathrm{TG}$ curves showed two steps. The first one resulting in a black residue of $\mathrm{PbS}$, confirmed by $\mathrm{X}$-ray diffraction measurements and by smell of $\mathrm{H}_{2} \mathrm{~S}$ in presence of hydrochloric acid. The second step was related to volatilization of the $\mathrm{PbS}$; resulting in a small amount of intermetallic $\mathrm{Pb}-\mathrm{Pt}$ at crucible, at $1030{ }^{\circ} \mathrm{C}$, according the $\mathrm{X}$-ray diffraction data.
Under air atmosphere (Fig. 1.i) the decomposition occurred with formation of a mixture of $\mathrm{PbS}$ and $\mathrm{PbSO}_{4}$, followed by oxidation to $\mathrm{PbSO}_{4}$ and a small amount lead oxysulphate, $\mathrm{Pb}_{3} \mathrm{O}_{2} \mathrm{SO}_{4}$, according the $\mathrm{X}$-ray diffraction results.

The DSC curve under $\mathrm{N}_{2}$ atmosphere (Fig. 2.e), showed a sharp endothermic peak, attributed to the melting, followed by an endothermic decomposition peak at $321^{\circ} \mathrm{C}$. The curve in air (Fig. 2.j) also suggests a melting process. In the sequence occurred the decomposition of compound with peaks at $320{ }^{\circ} \mathrm{C}$ and at $334{ }^{\circ} \mathrm{C}$, followed by the oxidation process represented by the exothermic peak at $453{ }^{\circ} \mathrm{C}$.

The TG-DTG curves for Piperidinedithicarbamates are shown in Fig. 3 under nitrogen and air atmospheres. The DSC curves under both atmospheres are in Fig. 4. Mass losses, temperature ranges and residues for the decomposition of all Pyr compounds are described in Table 5. The melting points and enthalpies are shown in Table 4.

\section{$\mathrm{NH}_{4}$ Pip}

The TG/DTG curves of this salt showed a single mass loss $\left(85-180^{\circ} \mathrm{C}\right)$, without residues in the crucible (Fig. 3.a). The DSC curves showed a sharp endothermic peak, at $172{ }^{\circ} \mathrm{C}$ and $175{ }^{\circ} \mathrm{C}$ under $\mathrm{N}_{2}$ (Fig. 2.a) and air (Fig. 2.f) atmospheres respectively, without evidence of melting. Experiment in an open glass tube showed that the compound sublimates without decomposition since the IR spectra of the sublimate product is identical to the original salt.

\section{NaPip}

This salt showed a very similar behaviour with the $\mathrm{NaPyr}$. The decomposition occurred in two steps under $\mathrm{N}_{2}$ (Fig. 3.b). The first relative to the loss of $2 \mathrm{H}_{2} \mathrm{O}$, in agreement with Kudela et al. report ${ }^{23}$. The second step is related to decomposition and formation of sodium polisulphide as residue under nitrogen ${ }^{27,28}$. Under air (Fig. 3.f) the TG curve showed the water loss was and formation of sodium sulphate in the range. All these residues were confirmed by $\mathrm{X}$-ray diffraction, being the most stable piperidine derivative in the series here studied.

The DSC curves for sodium salt showed three endothermic peaks under $\mathrm{N}_{2}$ atmosphere (Fig. 4.b). The first at $142{ }^{\circ} \mathrm{C}$ related to the water loss, the second a sharp peak at $302{ }^{\circ} \mathrm{C}$, attributed to a melting process. The last one at $338^{\circ} \mathrm{C}$, was attributed to the decomposition. Under air (Fig. 4.g) showed the loss of water (endothermic peaks at 148 and $165^{\circ} \mathrm{C}$ ), followed by complex exothermic processes of decomposition represented by the peaks at 291 and $320^{\circ} \mathrm{C}$ and oxidation to $\mathrm{Na}_{2} \mathrm{SO}_{4}$ at $417^{\circ} \mathrm{C}$. The melting is probably masked by the strong exothermic decomposition of the compound under oxidative atmosphere. 
Table 5. Mass loses and temperature range corresponding to the decomposition of the pip compounds.

\begin{tabular}{|c|c|c|c|}
\hline \multirow[t]{2}{*}{ Thermal Process } & \multirow[t]{2}{*}{ Temp. Interval $/{ }^{\circ} \mathrm{C}$} & \multicolumn{2}{|c|}{ Mass Loss or residue/ \% } \\
\hline & & $\mathrm{TG}$ & Calc. \\
\hline \multicolumn{4}{|l|}{$\mathrm{N}_{2}$ Atmosphere } \\
\hline NaPip. $2 \mathrm{H}_{2} \mathrm{O} \rightarrow \mathrm{NaPip}+2 \mathrm{H}_{2} \mathrm{O}$ & $64-126$ & $16.3^{\mathrm{a}}$ & 16.4 \\
\hline $\mathrm{NaPip} \rightarrow \mathrm{Na}_{2} \mathrm{~S}_{2}$ & $297-362$ & $25.2^{b}$ & 25.1 \\
\hline $\mathrm{ZnPip}_{2} \rightarrow \mathrm{ZnS}(+\mathrm{Zn})$ & $228-400$ & $24.6^{b}$ & 25.2 \\
\hline $\mathrm{ZnS} \rightarrow \mathrm{Zn}$ & $541-951$ & $16.8^{\mathrm{b}}$ & 17.0 \\
\hline $\mathrm{CdPip}_{2} \rightarrow \mathrm{CdS}+\mathrm{C}$ & $240-423$ & $37.2^{b}$ & 33.4 \\
\hline $\mathrm{CdS}_{(\mathrm{S})} \rightarrow \mathrm{CdS}_{(\mathrm{g})}$ & $660-954$ & $3.90^{\mathrm{b}}$ & 0 \\
\hline $\mathrm{PbPip}_{2} \rightarrow \mathrm{PbS}$ & $232-394$ & $46.0^{\mathrm{b}}$ & 45.3 \\
\hline $\mathrm{PbS}_{(\mathrm{s})} \rightarrow \mathrm{PbS}_{(\mathrm{g})}$ & $702-1030$ & $3.47^{\mathrm{b}}$ & 0 \\
\hline \multicolumn{4}{|l|}{ Air Atmosphere } \\
\hline $\mathrm{NaPip} .2 \mathrm{H}_{2} \mathrm{O} \rightarrow \mathrm{NaPip}+2 \mathrm{H}_{2} \mathrm{O}$ & $66-130$ & $16.1^{\mathrm{a}}$ & 16.4 \\
\hline $\mathrm{NaPip} \rightarrow \mathrm{Na}_{2} \mathrm{SO}_{4}$ & $233-324$ & $32.0^{\mathrm{b}}$ & 32.4 \\
\hline $\mathrm{ZnPip}_{2} \rightarrow \mathrm{ZnS}+\mathrm{ZnSO}_{3}$ & $226-379$ & $25.0^{\mathrm{b}}$ & - \\
\hline $\mathrm{ZnS}+\mathrm{ZnSO}_{3} \rightarrow \mathrm{ZnO}+\mathrm{ZnSO}_{4}$ & $379-444$ & $23.1^{b}$ & - \\
\hline $\mathrm{ZnSO}_{4} \rightarrow \mathrm{ZnO}$ & $690-748$ & $20.3^{b}$ & 21.0 \\
\hline $\mathrm{CdPip}_{2} \rightarrow \mathrm{CdS}+\mathrm{C}$ & $241-360$ & $37.5^{b}$ & 33.4 \\
\hline $\mathrm{CdS} \rightarrow \mathrm{Cd}_{3} \mathrm{OSO}_{4}$ & $482-739$ & $35.7^{\mathrm{b}}$ & 34.5 \\
\hline $\mathrm{Cd}_{3} \mathrm{OSO}_{4} \rightarrow \mathrm{CdO}$ & $799-916$ & $30.1^{b}$ & 29.7 \\
\hline $\mathrm{PbPip}_{2} \rightarrow \mathrm{PbS}\left(+\mathrm{Pb}_{2} \mathrm{OSO}_{4}\right)$ & $253-389$ & $49.5^{b}$ & 45.3 \\
\hline $\mathrm{PbS} \rightarrow \mathrm{Pb}_{2} \mathrm{OSO}_{4}$ & $389-508$ & $52.0^{\mathrm{b}}$ & 50.2 \\
\hline $\mathrm{Pb}_{2} \mathrm{OSO}_{4} \rightarrow \mathrm{PbSO}_{4}$ & $549-730$ & $57.9^{b}$ & 57.5 \\
\hline
\end{tabular}

- not calculated, mixture; a: relative to a mass loss; b: relative to the residue.

ZnPip 2

TG/DTG curves of zinc compound showed decomposition in a single step under nitrogen atmosphere (Fig. 3.c) resulting in a white residue confirmed by $\mathrm{HCl}$ test and $\mathrm{X}$-ray diffraction as the. This is slowly reduced to $\mathrm{Zn}^{\circ}$. Under air atmosphere (Fig. 3.g) there was three steps of decomposition, resulting in a mixture of $\mathrm{ZnS}$ and $\mathrm{ZnSO}_{3}$ at $379{ }^{\circ} \mathrm{C} ; \mathrm{ZnO}$ and $\mathrm{ZnSO}_{4}$ at $444{ }^{\circ} \mathrm{C}$ and $\mathrm{ZnO}$ at $748{ }^{\circ} \mathrm{C}$. All these compounds were identified by their $\mathrm{X}$-ray diffraction patterns.

The DSC curves under $\mathrm{N}_{2}$ atmosphere (Fig. 4.c), showed a endothermic peaks at 228 and $332{ }^{\circ} \mathrm{C}$, attributed to melting and decomposition of the compound respectively. Under air atmosphere (Fig. 4.h) endothermic peak at $228{ }^{\circ} \mathrm{C}$ is observed related to the melting, in agreement with nitrogen experiments. The decomposition of the complex is represented by the peaks at 329 and at $347{ }^{\circ} \mathrm{C}$.

The melting point is in disagreement with that of $\mathrm{Ok}-$ tavec et al. ${ }^{30}$, who describes that it occurs at $288-289^{\circ} \mathrm{C}$.

\section{$\mathrm{CdPip}_{2}$}

The TG/DTG curves showed that the decomposition occurred in two steps under $\mathrm{N}_{2}$ atmosphere (Fig. 3.d) generating $\mathrm{CdS}$ which is present as a yellow residue, confirmed by X-ray diffraction and $\mathrm{HCl}$ test. The difference between the TG and calculated residues is due to the presence of carbonaceous residue, represented by amorphous phase in $\mathrm{X}$-ray diffraction. Finally volatilization of $\mathrm{CdS}$ is observed, with a black residue of $3.9 \%$ exactly the difference at 423 ${ }^{\circ} \mathrm{C}$, attributed to the carbonaceous material.

Under air atmosphere (Fig. 3.h) the main decomposition step occurred producing $\mathrm{CdS}$ and carbonaceous material followed by oxidation lead to the $\mathrm{Cd}_{3} \mathrm{OSO}_{4}$ and finally $\mathrm{CdO}$ as the final product of decomposition. All these products were characterised by X-ray diffraction patterns.

The DSC curves evidenced the occurrence of melting represented by the peaks at $258{ }^{\circ} \mathrm{C}$ under $\mathrm{N}_{2}$ (Fig. 4.d) and at $258{ }^{\circ} \mathrm{C}$ under air atmosphere (Fig. 4i). Decomposition were represented by the endothermic peak at 323 under $\mathrm{N}_{2}$. 

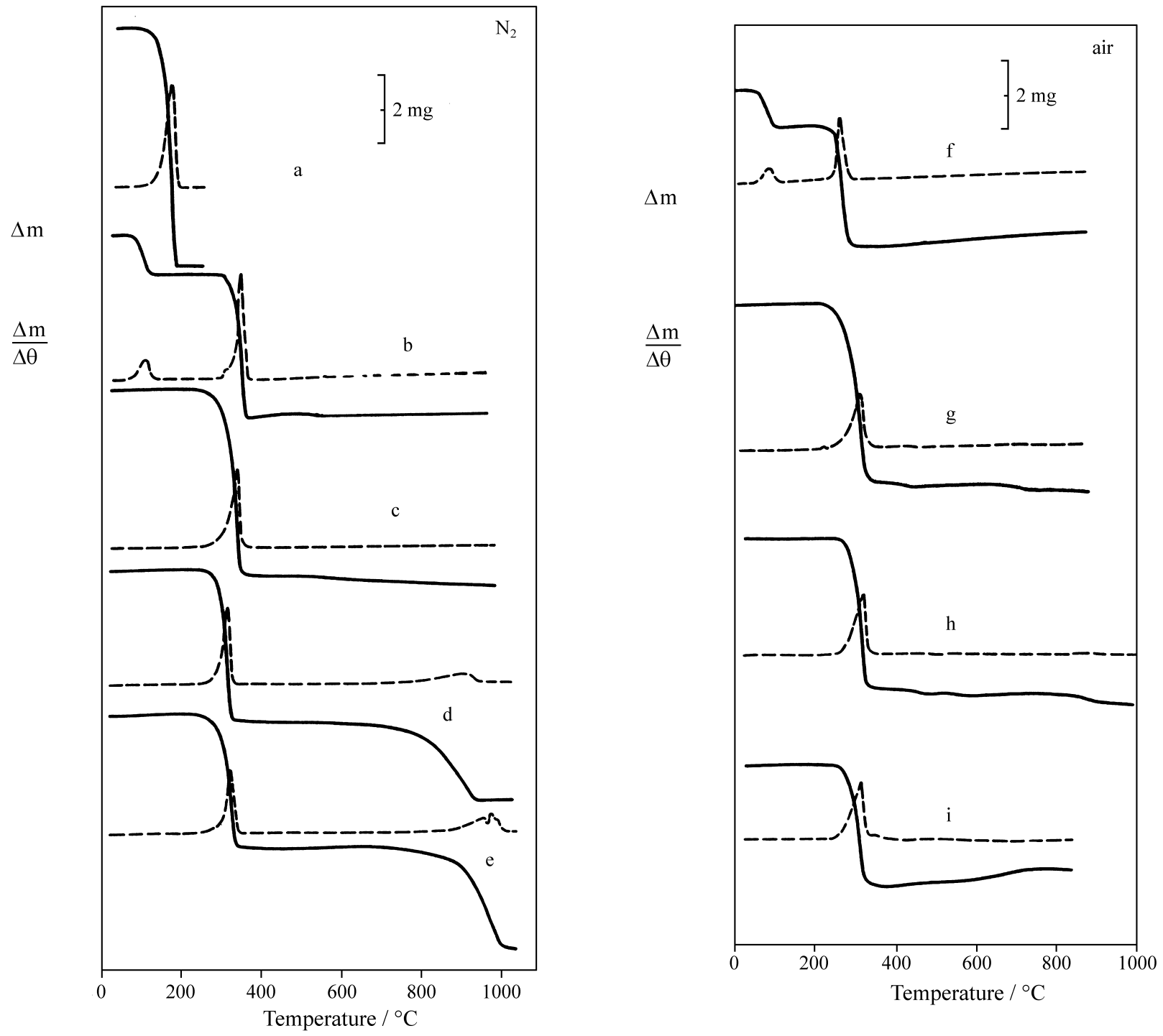

Figure 3. TG (solid line) and DTG (dashed line) curves for the Piperidinedithiocarbamates under $\mathrm{N}_{2}$ atmosphere : a) $\mathrm{NH}_{4}^{+}$; b) $\mathrm{Na}^{+}$; c) $\mathrm{Zn}^{2+}$; d) $\mathrm{Cd}^{2+}$; e) $\mathrm{Pb}^{2+}$; and under air: f) $\mathrm{Na}^{+} ;$g) $\mathrm{Zn}^{2+} ;$ h) $\mathrm{Cd}^{2+}$ and i) $\mathrm{Pb}^{2+}$.

Under air the peaks at 321 and $335^{\circ} \mathrm{C}$ were attributed to the decomposition, and the exothermic peak at $448^{\circ} \mathrm{C}$ was related with the production of $\mathrm{Cd}_{3} \mathrm{OSO}_{4}$.

\section{PbPip $_{2}$}

The TG/DTG curves under nitrogen (Fig. 3.e) for the lead compound showed a decomposition, resulting in a black residue of $\mathrm{PbS}$ confirmed by $\mathrm{X}$-ray diffraction and test with $\mathrm{HCl}$. Above $700{ }^{\circ} \mathrm{C}$, volatilization of the $\mathrm{PbS}$ occurred, similarly to the $\mathrm{PbPyr}_{2}$.

Under air atmosphere (Fig. 3.i) a decomposition occurred, with formation of a mixture of $\mathrm{PbS}$ and traces of lead oxysulphate $\mathrm{Pb}_{2} \mathrm{OSO}_{4}$. Then the mixture is converted to $\mathrm{Pb}_{2} \mathrm{OSO}_{4}$, and finally $\mathrm{PbSO}_{4}$. The residues were identified by X-ray diffraction.
The DSC curve under $\mathrm{N}_{2}$ atmosphere (Fig. 4.e), showed a sharp endothermic peak at $244{ }^{\circ} \mathrm{C}$ attributed to melting, followed by a decomposition peak at $323^{\circ} \mathrm{C}$. The curve under air atmosphere (Fig. 4.j) showed the melting peak. At the sequence the decomposition of the compound is observed with peaks at $316^{\circ} \mathrm{C}, 333{ }^{\circ} \mathrm{C}$, and $416^{\circ} \mathrm{C}$.

\section{Final Comments}

It was expected that the angular tension in the fivemembered pyrrolidine ring, should lead to a weakening of the $\mathrm{C}-\mathrm{N}$ ring bonds favouring its rupture generating the metallic thiocyanate but this is not true.

According to the results obtained here, both cyclic DTC, decomposed preferentially in a direct way, without the formation of a thiocyanate intermediate, in a different 

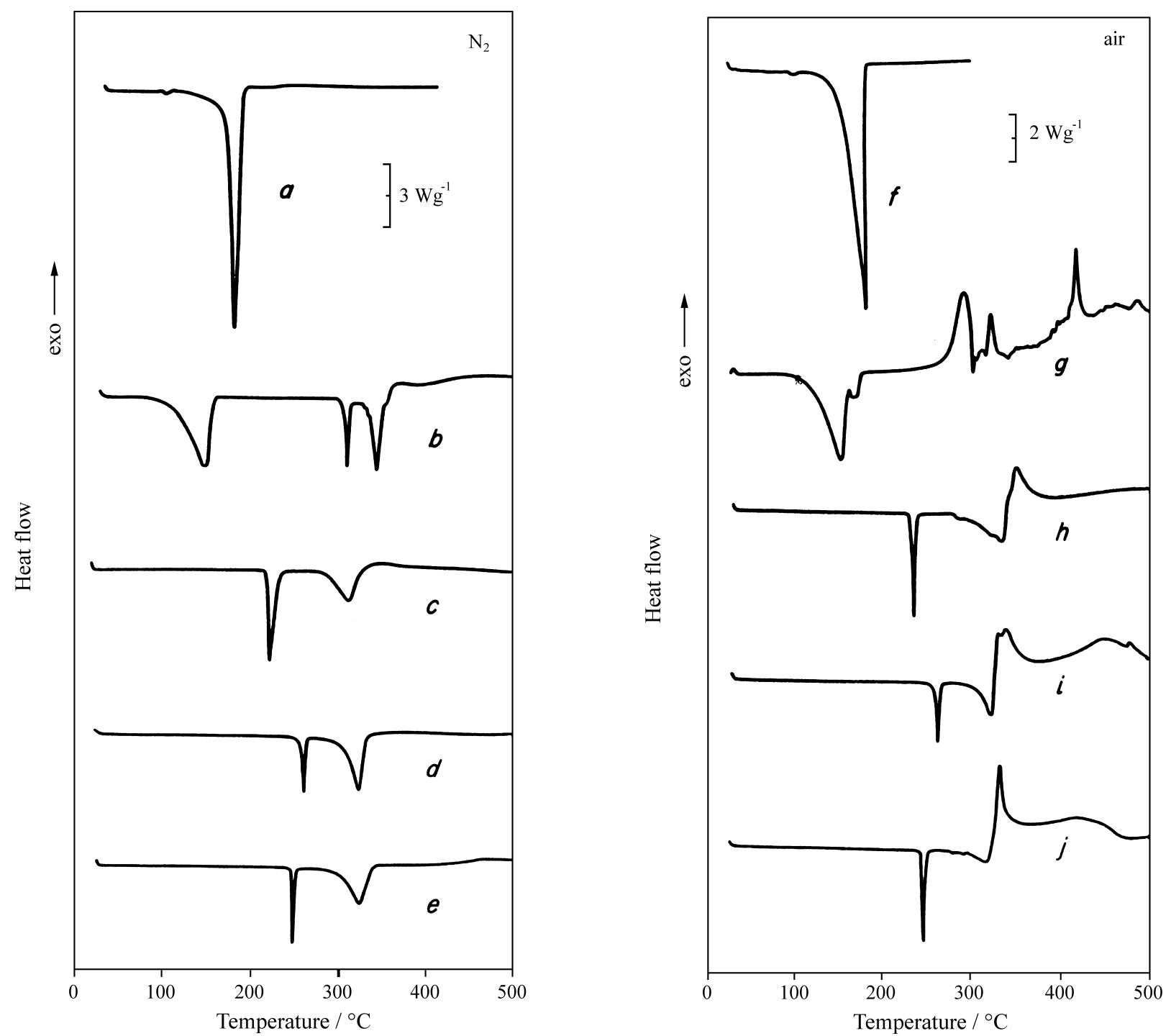

Figure 4. DSC curves for the Piperidinedithiocarbamates under $\mathrm{N}_{2}$ atmosphere: a) $\mathrm{NH}_{4}^{+}$; b) $\mathrm{Na}^{+}$; c) $\mathrm{Zn}^{2+}$; d) $\mathrm{Cd}^{2+}$; e) $\mathrm{Pb}^{2+}$; and under air: f) $\mathrm{NH}_{4}^{+}$g) $\mathrm{Na}^{+}$; h) $\mathrm{Zn}^{2+}$; i) $\mathrm{Cd}^{2+}$ and j) $\mathrm{Pb}^{2+}$.

behaviour described to non cyclic derivatives ${ }^{1}$. The CdPyr suggested the unique exception.

The most remarkable difference in the decomposition as a function of the aminic group was observed for the ammonium salts.

Some oxysulphates were obtained as products, suggesting that the thermal decomposition of the dithiocarbamate complexes may be an useful synthetic route to obtain such compounds.

\section{References}

1. Sharma, A.K. Thermochim. Acta 1986, 104, 339.

2. Magee, R.J.; Hill, J.O. Rev. Anal. Chem. 1985, 8, 5.

3. Bond, A.M.; Martin, R.L. Coord. Chem. Rev. 1984, $54,23$.
4. Sengupta, S.K.; Kumar, S. Termoch. Acta 1984, 72, 349.

5. Hill, J.O.; Magee, R.J. Rev. Inorg. Chem. 1981, 3, 141. 6. Coucovanis, D. Progr. Inorg. Chem. 1979, 26, 301.

7. Coucovanis, D. Progr. Inorg. Chem. 1970, 11, 233.

8. Hulanicki, A. Talanta 1967, 14, 1371.

9. Thorn, G.D.; Ludwig, R.A. The Dithiocarbamates and Related Compounds, Elsevier, Amsterdam, 1962.

10. Vandebeek, R.R.; Joris, S.J.; Aspila, K.I.; Chakrabarti, C.L.Can. J. Chem. 1970, 48, 2204.

11. Santos, D.M.; Lucas, P.O.; Cavalheiro, E.T.G.; Nóbrega, J.A. $5^{\text {th }}$ Rio Symposium on Atomic Spectrometry, Cancun, Mexico, 1998.

12. Datta, R.N.; Das, P.K.; Basu, D.K. Rubber Chem. Technol. 1984, 57, 879. 
13. Fukumoto, H.; Tanaka, K.; Kawagishi, Y. Jpn. Kokai Tokkio Koho, J.P. 61.246.760, 1986.

14. Fukumoto, H.; Tanaka, K.; Kawagishi, Y. Jpn. Kokai Tokkio Koho, J.P. 61.246.757, 1986.

15. Fernandez-Alba, A.; Perez-Alvarez, I.J.; Martinez-Vidal, J.L.; Gonzalez-Pradas, E. J. Thermal Anal. 1992, $211,271$.

16. Diaz, J.R.; Zigon, M.; Gomicek, S. Org. Mass Spectrom. 1981, 16, 12.

17. Gomicek, S.; Golic, L.; Lengar, Z. Anal. Chim. Acta 1975, 79, 296.

18. Gomicek, S.; Lengar, Z.; Cernetic, J.; Hudnik, V. Anal. Chim. Acta 1974, 73, 97.

19. Sceney, C.G.; Hill, J.O.; Magee, R.J. Termochim. Acta 1975, 11, 301.

20. Lee, A.W.M.; Chan, W.H.; Chiu, C.M.L.; Tang, K.T. Anal. Chim. Acta 1989, 218, 157.

21. Oktavec, D.; tefanec, J.; Síle, B.; Konecny, V.; Garaj, J. Collect. Czech. Chem. Commun. 1979, 44, 2487.
22. Desseyn, H.O.; Fabretti, A.C.; Forghieri, F.; Preti, C. Spectrochim. Acta 1985, 41A, 1105.

23. Kudela, S.; Garaj, J.; Hofbauerova, H.; Kettmann, V. Collect. Czech. Chem. Commun. 1980, 45, 800.

24. Kellner, R. Mikrochim. Acta 1975, II, 24.

25. Kellner, R.; Prokopowski, P.; Malissa, H. Anal. Chim. Acta 1974, 68, 401.

26. Vogel, A.I. Química analítica Qualitativa; Trad. A. Gimeno; Mestre Jou, São Paulo, 1979.

27. Forghieri, F.; Preti, C.; Tassi, L.; Tosi, G. Polyhedron 1988, 7, 1231.

28. Fabretti, A.C.; Forghieri, F.; Giusti, A.; Preti, C.; Tosi, G.Spectrochimica Acta 1984, 40A, 343.

29. Huhey, J.E.; Keiter, E.A.; Keiter, R.L. Inorganic Chemistry, $4^{\text {th }}$ Edition, Harper Collins, New York, 344-348, 1993.

30. Oktavec, D.; tefanec, J.; Síle, B.; Konecny, V.; Beinrohr, E.; Garaj, J. Collect. Czech. Chem. Commun. 1982, 47, 2867. 